\title{
REPRESENTASI SISWA SMP DALAM MEMECAHKAN MASALAH MATEMATIKA DITINJAU DARI KEMAMPUAN MATEMATIKA
}

\author{
Imelda Lette \\ Program Studi Pendidikan Matematika, FMIPA, Unesa, e-mail: imeldalette@mhs.unesa.ac.id \\ Janet Trineke Manoy \\ Program Studi Pendidikan Matematika, FMIPA, Unesa, e-mail: janettrinekemanoy@unesa.ac.id
}

\begin{abstract}
Abstrak
Representasi adalah bentuk interpretasi pemikiran siswa yang digunakan untuk menemukan solusi dari suatu masalah. Adapun representasi matematis siswa dalam memecahkan masalah dipengaruhi oleh tingkat kemampuan matematika. Penelitian ini merupakan penelitian deskriptif kualitatif dengan tujuan untuk mendeskripsikan representasi siswa SMP Kemala Bhayangkari 1 Surabaya yang berkemampuan matematika tinggi dan sedang dalam memecahkan masalah matematika menggunakan metode tes dan wawancara. Subjek yang digunakan dalam penelitian ini adalah satu siswa dengan kemampuan matematika tinggi dan satu siswa berkemampuan matematika sedang. Tahap pemecahan masalah yang digunakan adaah tahap pemecahan masalah Polya meliputi memahami masalah, membuat rencana, melaksanakan rencana, dan memeriksa kembali. Hasil penelitian menunjukkan bahwa subjek dengan kemampuan matematika tinggi pada tahap memahami masalah, memunculkan representasi verbal dan representasi simbol. Pada tahap membuat rencana, memunculkan representasi verbal dan simbol. Pada tahap melaksanakan rencana, menggunakan representasi simbol yang sudah tepat. Pada tahap memeriksa kembali menggunakan representasi verbal untuk menuliskan kesimpulan dari jawaban yang diberikan, tetapi tidak melakukan perhitungan ulang. Sedangkan subjek dengan kemampuan matematika sedang pada tahap memahami masalah, memunculkan representasi verbal. Tahap membuat rencana, membuat representasi verbal dan simbol. Tahap melaksanakan rencana, menggunakan representasi simbol. Tahap memeriksa kembali, menggunakan representasi verbal untuk menuliskan kesimpulan dari apa yang dikerjakan..
\end{abstract}

Kata kunci: representasi, kemampuan matematika, masalah matematika

\begin{abstract}
Representation is a form of interpretation of students' thinking that is used to find solutions to a problem. The mathematical representation of students in solving problems is influenced by the level of mathematical abilities. This study is a qualitative descriptive study with the aim of describing the representation of students of Kemala Bhayangkari 1 Surabaya Middle School who have high and moderate mathematical abilities in solving mathematical problems using test and interview methods. The subjects used in this study were one student with high mathematical abilities and one student with moderate mathematical abilities. The problem solving phase used is the Polya problem solving phase which includes understanding the problem, making a plan, implementing the plan, and checking it again. The results showed that subjects with high mathematical abilities at the stage of understanding problems, gave rise to verbal representations and symbolic representations. At the stage of making a plan, bring up verbal representations and symbols. At the stage of implementing the plan, use the appropriate symbol representation. At the re-checking stage, use verbal representations to write conclusions from the answers given, but do not recalculate. While subjects with mathematical abilities are at the stage of understanding the problem, giving rise to verbal representations. The stage of making plans, making verbal representations and symbols. The stage carries out the plan, using symbol representation. The stage of re-checking, using verbal representations to write conclusions of what was done
\end{abstract}

Keywords: representation, mathematical problems, mathematical capabilities

\section{PENDAHULUAN}

National Countil of Mathematics atau NCTM (2000:7) menetapkan lima standar yang mendeskripsikan keterkaitan pemahaman matematika dan kompetensi matematika yang harus dimiliki oleh siswa meliputi: 1) Pemecahan masalah, 2) Komunikasi, 3) Penalaran, 4) Koneksi, 5) Representasi. NCTM (2000) bahwa pemecahan masalah merupakan bagian integral dalam pembelajaran matematika, sehingga hal tersebut tidak 
boleh dilepaskan dari pembelajaran matematika. Bentuk representasi seperti objek fisik, gambar, diagram, grafik dan simbol dapat membantu siswa mengkomunikasikan pikirannya (NCTM, 2000).

Yanti (2017) mengatakan bahwa Representasi dan pemecahan masalah memiliki keterkaitan yang erat. Keterkaitan ini terjadi saat siswa mengkonstruksi representasi yang tepat dengan permasalahan untuk memperoleh solusi yang tepat. Jadi dalam melakukan pemecahan masalah, diperlukan kemampuan seseorang untuk memberi pertimbangan terhadap bentuk representasi yang dilibatkan. Hal tersebut menunjukkan bahwa kecakapan seseorang dalam mengubah suatu representasi akan mempengaruhi kecakapannya dalam mencari solusi pemecahan masalah. Sehingga suatu masalah yang rumit dapat menjadi sederhana jika menggunakan pemecahan masalah yang tepat.

Dalam memecahkan masalah, siswa akan mengalami kesulitan tanpa kemampuan representasi, artinya kemampuan yang dimiliki siswa tidak dapat digunakan secara langsung untuk mendapatkan solusi dari suatu masalah (Murni, 2013). Lebih lanjut dijelaskan bahwa siswa perlu merancang suatu bentuk atau model yang mewakili masalah untuk memudahkan siswa dalam memperoleh solusi yang diinginkan. Representasi bagian dari kegiatan merancang sesuatu yang mewakili masalah, dengan demikian, dalam proses menemukan solusi atau jawaban suatu masalah, terlebih dulu siswa perlu untuk membuat representasi.

Keterkaitan antara kemampuan representasi dengan kemampuan pemecahan masalah ditunjukkan dari beberapa hasil penelitian. Murni (2013) dalam penelitianya menyatakan bahwa penyusunan rencana pemecahan masalah sangat erat kaitannya dengan kemampuan representasi matematis siswa. Selain itu, penelitian yang dilakukan oleh Alhadad (2010) juga menyimpulkan bahwa peningkatan kemampuan

representasi matematis dapat menunjang peningkatan kemampuan pemecahan masalah matematis. Representasi yang dimunculkan siswa merupakan ide atau konsep matematika yang diungkapkan siswa sebagai alat yang dapat digunakan untuk menemukan solusi pemecahan masalah matematika (NCTM, 2000). Lebih detail Goldin (2002) menggungkapkan bahwa representasi dapat dikatakan sebagai pengungkapan ide- ide matematika dengan menggunakan berbagai cara seperti: bahasa lisan, simbol, gambar, grafik, atau menggunakan anggota fisik.

Kemampuan representasi siswa merupakan faktor keberhasilan siswa dalam memecahkan suatu masalah (Kartini, 2009). Ketika siswa dihadapkan pada suatu situasi masalah matematika dalam pembelajaran di kelas, mereka akan berusaha memahami masalah tersebut dan menyelesaikannya dengan cara-cara yang mereka ketahui.
Masalah yang menarik dan non rutin yang disajikan akan membuat siswa untuk berpikir menggunakan informasi yang tersedia dan mengaitkannya dengan pengetahuan yang sudah mereka miliki sebelumnya, masalah tersebut juga memungkinkan untuk diselesaikan dengan lebih dari satu cara. Salah satu pengetahuan yang diharapkan dalam memecahkan masalah matematika ini, yaitu kemampuan merepresentasikan pemecahan masalah matematika dengan menggunakan representasi.

Kemampuan matematika siswa ini berkaitan dengan kemampuan dalam memecahkan masalah matematika. Mandur, dkk (2013:8) mengatakan bahwa representasi matematika berkontribusi secara signifikan terhadap kemampuan matematika baik secara langsung maupun tidak langsung. Berdasarkan Hwang, et. al (2007:192) tinggi rendahnya kemampuan matematika yang diraih siswa ditentukan oleh kemampuan representasi. Siswa yang mempunyai kemampuan representasi baik, cenderung kemampuan matematikanya tinggi. Berdasarkan penelitian Harianti (2016) kemampuan matematika rendah dalam menyelesaikan tes pemecahan masalah representasi yang di munculkan hanya representasi teks tertulis atau kata- kata dan penyelesaiannya juga tidak sesuai dengan indikator representasi siswa. Sehingga peneliti hanya mengambil subjek kemampuan matematika tinggi dan sedang. Berdasarkan pernyataan tersebut, dimungkinkan representasi menyelesaikan masalah siswa berbeda-beda berdasarkan tingkat kemampuan matematika.

Materi dalam Penelitian ini menggunakan materi sistem persamaan linear dua variabel (SPLDV) karena berdasarkan penelitian terdahulu seperti Selviani (2015) menyatakan bahwa Siswa merasa kesulitan dengan pemahaman soal cerita yang diberikan oleh guru di sekolah. Kesulitan terjadi akibat sudah tertanam di pikiran siswa bahwa soal cerita itu sulit serta kesulitan dalam menerjemahkan soal yakni dalam membuat model matematika. Dalam penelitian ini subjek yang akan diambil yaitu siswa SMP kelas VIII, pemilihan tersebut dilakukan dengan pertimbangan bahwa pada jenjang ini merupakan tahap di mana siswa berada pada tahap operasi formal dan memungkinkan adanya keragaman representasi oleh siswa. Jika hal ini diketahui, maka akan memudahkan guru untuk merancang pembelajaran dengan memperhatikan kemampuan representasi siswa.

Adapun tujuan dari penelitian ini yaitu: mendeskripsikan representasi siswa SMP Bhayangkara 1 Surabaya yang berkemampuan matematika tinggi dan sedang dalam memecahkan masalah matematika. Kajian teoritik yang berkaitan dengan masalah yang diteliti yaitu: representasi, representasi matematik, masalah matematika, pemecahan masalah, representasi dalam memecahkan masalah matematika dan kemampuan matematika. 


\section{METODE}

Pendekatan yang digunakan dalam penelitian ini adalah pendekatan kualitatif.sedangkan Jenis penelitian ini termasuk penelitian deskriptif kualitatif yang bertujuan untuk mendeskripsikan tentang suatu keadaan secara objektif. Penelitian ini dirancang untuk mendeskripsikan representasi siswa VIII SMP Kemala Bhayangkari 1 Surabaya pada semester genap tahaun ajaran 2018/2019 yang berkemampuan matematika tinggi dan sedang dalam memecahkan masalah.

Data yang digunakan dalam penelitian ini adalah hasil tes kemampuan matematika, tes pemecahan masalah matematika dan hasil wawancara. Instrumen pengumpulan data yang digunakan yaitu peneliti sebagai instrumen utama dan instrumen pendukung terdiri dari:

a. Lembar Tes Kemampuan Matematika

b. Lembar Tes Pemecahan Masalah Matematika

c. Pedoman wawancara

Teknik yang digunakan untuk mengumpulkan data dalam penelitian ini ialah keterangan atau informasi yang terkait dengan metode wawancara, hasil dari wawancara digunakan sebagai pembanding atau acuan terhadap hasil pengerjaan subjek setelah subjek penelitian melaksanakan soal tes.

Teknik analisis data yang digunakan dalam penelitian ini adalah sebagai berikut.

1. Teknik Analisis Data Hasil Tes

Kemampuan Matematika

2. Teknik Analisis Data Hasil Tes

Pemecahan Masalah

Matematika

3. Teknik Analisis Data Hasil Wawancara
a. Reduksi Data
b. Penyajian Data
c. Penarikan Kesimpulan

\section{HASIL DAN PEMBAHASAN}

Setelah memperoleh 2 subjek penelitian yaitu siswa berkemampuan matematika tinggi dan sedang, peneliti memberikan lembar tes pemecahan masalah matematika kepada 2 subjek tersebut. Hasil tes pemecahan masalah matematika yang dilakukan oleh siswa berkemampuan matematika tinggi dan dan sedaang dipaparkan sebagai berikut.

Analisis Data Representasi Subjek Berkemampuan Matematika Tinggi (ST) Terhadap Tes Pemecahan Masalah (TPM) Pada Tahap Memahami Masalah Berdasarkan hasil penyelesaian masalah kemudian dianalisis sehingga terungkap bahwa dalam memecahkan masalah yang diberikan subjek ST menggunakan representasi simbol dengan memisalkan apa yang diketahui dari soal dan menggunakan representasi verbal/kata-kata untuk menjelaskan apa yang ditanyakan dari soal. Lebih jelasnya dapat dilihat pada Gambar 1 hasil penyelesaian subjek ST pada tahap memahami masalah.

Jawab

diket: Bulan Mel: $2 x$ bulan April ( $x$ )

Bulan Juni $=6 x$ bulan Mer $(M)$

Bulan April dan Bulan Juni: go porsi

dit: Trumlan Dorsi makonan Dada Bulan April =... Gambar 1. Hasil penyelesaian subjek ST

Analisis Data Representasi Subjek Berkemampuan Matematika Tinggi (ST) Terhadap Tes Pemecahan Masalah (TPM) Pada Tahap Membuat Rencana

Berdasarkan hasil penyelesaian masalah kemudian dianalisis sehingga terungkap bahwa dalam memecahkan masalah yang diberikan ST membuat permisalan dengan menggunakan representasi simbol terlebih dahulu seperti yang telah dilakukan pada tahap sebelumnya yaitu tahap yang diketahui, Kemudian menggunakan metode substitusi dengan memanfaatkan persamaan yang diperoleh pada tahap sebelumnya. Lebih jelasnya dapat dilihat pada Gambar 2 hasil penyelesaian subjek ST pada tahap membuat rencana

$\Rightarrow$ Subtitusi: $x+6+2 x=90$

$\tan 3 x+6=90$

$$
\begin{aligned}
& 3 x=90-6 \\
& 3 x: 84 \\
& x: 84: 3=28
\end{aligned}
$$

Gambar 2 Lembar Jawaban ST pada tahap Membuat Rencana

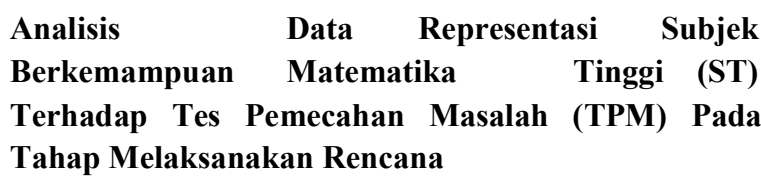

$$
\begin{aligned}
& \text { Jawab: Ansy Mel: } M: 2 x \\
& \text { Jon: }:=2 x \\
& \text { April dan Juni: } 90 \text { pors } \\
& \text { : } x+y: 90 \\
& \Rightarrow \text { Subtitusi: } x+6+2 x=90 \\
& x+3 x+6=90 \\
& 3 x: 90-6 \\
& 3 x: 84 \\
& x: 84: 3: 28
\end{aligned}
$$

Gambar 3 Lembar Jawaban ST dalam Tahap

$$
\text { Melaksanakan Rencana }
$$

Berdasarkan hasil penyelesaian masalah kemudian dianalisis sehingga terungkap bahwa dalam memecahkan 
masalah yang diberikan ST memanipulasi ekspresi matematika pada pemodelan yang memuat representasi simbol dengan mensubstitusi persamaan satu dengan persamaan yang lain sehingga memperoleh hasil yang diinginkan. Lebih jelasnya dapat dilihat pada Gambar 3 hasil penyelesaian subjek ST pada tahap melaksanakan rencana.

Analisis Data Representasi Subjek Berkemampuan Matematika Tinggi (ST) Terhadap Tes Pemecahan Masalah (TPM) Pada Tahap Memeriksa Kembali

Berdasarkan hasil penyelesaian masalah kemudian dianalisis sehingga terungkap bahwa dalam memecahkan masalah yang diberikan ST menuliskan kesimpulan menggunakan representasi verbal/teks tertulis untuk memperjelas jawaban yang ditanyakan pada permasalahan. Lebih jelasnya dapat dilihat pada Gambar 4 hasil penyelesaian subjek ST pada tahap memeriksa kembali.

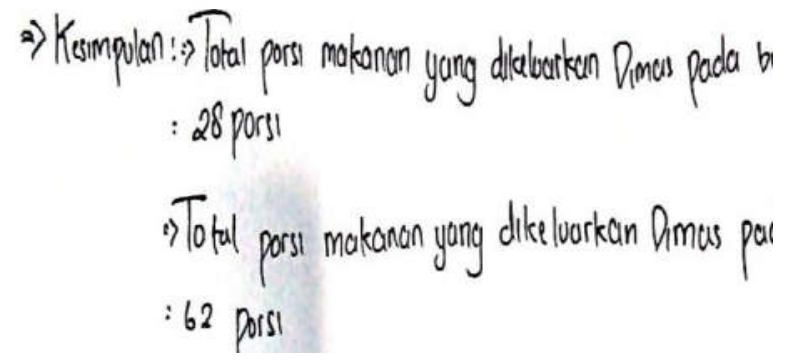

Gambar 4 Lembar Jawaban ST pada tahap Memeriksa Kembali

Analisis Data Representasi Subjek Berkemampuan Matematika Sedang (SS) Terhadap Tes Pemecahan Masalah (TPM) Pada Tahap Memahami Masalah

Berdasarkan hasil penyelesaian masalah kemudian dianalisis sehingga terungkap bahwa dalam memecahkan masalah yang diberikan SS menggunakan representasi verbal/kata-kata untuk menjelaskan apa yang diketahui dan ditanyakan ditanyakan dari soal. Lebih jelasnya dapat dilihat pada Gambar 5.

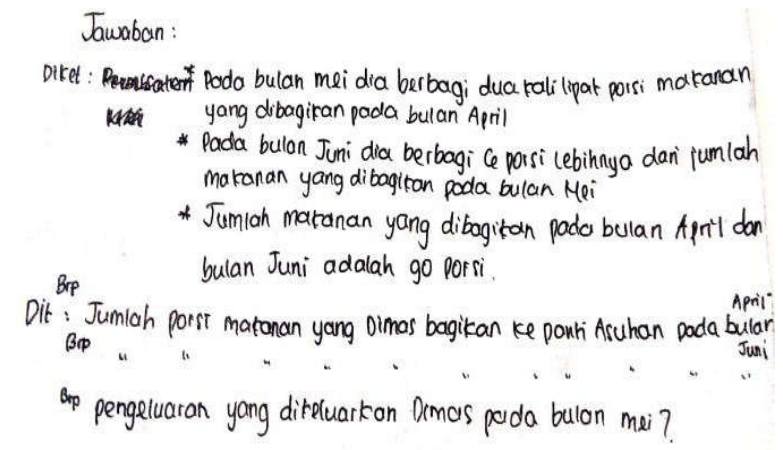

Gambar 5 Lembar Jawaban SS dalam Tahap Memahami Masalah
Analisis Data Representasi Subjek Berkemampuan Matematika Sedang (SS) Terhadap Tes Pemecahan Masalah (TPM) Pada Tahap Membuat Rencana

Berdasarkan hasil penyelesaian masalah kemudian dianalisis sehingga terungkap bahwa dalam memecahkan masalah yang diberikan SS membuat permisalan dengan menggunakan representasi simbol, Kemudian menggunakan metode substitusi dengan memanfaatkan persamaan yang diperoleh. Lebih jelasnya dapat dilihat pada Gambar 6 hasil penyelesaian subjek SS pada tahap membuat rencana

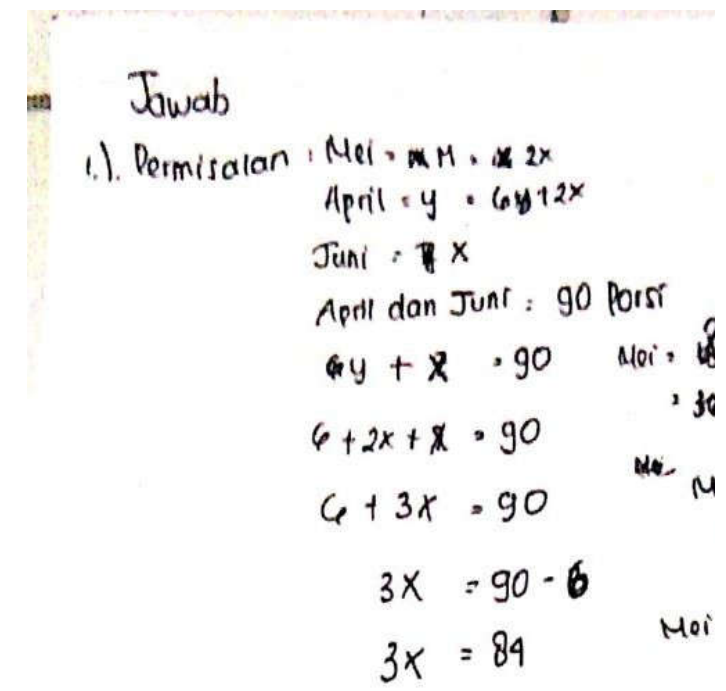

Gambar 6 Lembar Jawaban SS dalam Tahap Membuat

$$
\text { Rencana }
$$

Berdasarkan analisis di atas subjek dengan kemampuan matematika berbeda dalam memecahkan masalah menggunakan beberapa representasi. Representasi yang muncul dari kedua subjek adalah representasi simbol dan representasi verbal/teks tertulis. Adapun representasi yang dimunculkan oleh masing- masing subjek dideskripsikan sebagai berikut.

\section{Representasi Subjek Berkemampuan Matematika Tinggi (ST)}

Dalam memecahkan masalah, subjek berkemampuan matematika tinggi mampu menyelesaikan soal dengan baik, ST juga menggunakan empat tahapan Polya, yaitu memahami masalah, membuat rencana, melaksanakan rencana dan memeriksa kembali. Berikut merupakan representasi ST dalam memecahkan masalah SPLDV.

1. Pada tahap memahami masalah, ST menyajikan informasi yang diketahui dengan menggunakan representasi simbol dengan membuat permisalan kemudian membuat model matematika atau persamaan. Seperti simbol x menyatakan jumlah porsi makanan yang dibagikan pada bulan April, simbol y menyatakan jumlah porsi makanan yang dibagikan pada bulan Juni, simbol $m$ dengan menyatakan pengeluaran pada bulan 
Mei. Kemudian menuliskan persamaan yang diketahui $\mathrm{m}=2 \mathrm{x}, \mathrm{y}=6+2 \mathrm{x}, \mathrm{x}+\mathrm{y}=90$. Selain itu ST juga menyajikan informasi yang ditanya dalam bentuk representasi verbal/teks tertulis, yakni berapa jumlah porsi makanan yang Dimas bagikan ke panti asuhan

2. Pada tahap membuat rencana penyelesaian, ST menggunakan representasi simbol untuk membuat permisalan, seperti yang telah dilakukan pada tahap sebelumnya, dalam menyelesaikan masalah menggunakan metode substitusi dengan memanfaatkan persamaan yang sudah diperoleh dari soal. ST mampu menjelaskan rencana pemecahan masalah menggunakan kata-kata, dan menyusun strategis pemecahan masalah berdasarkan informasi pada soal.

3. Pada tahap melaksanakan rencana penyelesaian, ST dalam menyelesaikan masalah menggunakan representasi simbol dengan menggunakan metode substitusi dengan memanfaatkan persamaan yang sudah diperoleh dari soal.

4. Pada tahap memeriksa kembali, ST menggunakan representasi verbal/teks tertulis. Tanpa memeriksa kembali langkah-langkah penyelesaian yang telah dilakukan ST menyakini bahwa jawabannya sudah benar, kemudian dalam menuliskan kesimpulan berupa kalimat untuk memperjelas jawaban apa yang ditanyakan

\section{Representasi Subjek Berkemampuan Matematika Sedang (SS)}

Dalam memecahkan masalah, subjek berkemampuan matematika sedang mampu menyelesaikan soal TPM dengan baik, walaupun ada kesalahan dalam perhitungan, SS juga menggunakan empat tahapan Polya, yaitu memahami masalah, membuat rencana, melaksanakan rencana dan memeriksa kembali. Berikut merupakan representasi SS dalam memecahkan masalah SPLDV.

pada bulan April

1. Pada tahap memahami masalah, SS menyajikan informasi yang diketahui dengan menggunakan representasi verbal/teks tertulis untuk menulis kembali apa yang diketahui dari soal. Seperti pada bulan Mei dia berbagi dua kali lipat porsi makanan yang dibagikan pada bulan April, pada bulan Juni dia berbagi 6 porsi lebihnya dari jumlah makanan yang dibagikan pada bulan Mei, jumlah makanan yang dibagikan pada bulan April dan Juni adalah 90 porsi. Selain itu SS juga menyajikan informasi yang ditanya dalam bentuk representasi verbal/teks tertulis, yakni berapa jumlah porsi makanan yang Dimas bagikan ke panti asuhan pada bulan April dan Juni serta pengeluaran pada bulann Mei.

2. Pada tahap membuat rencana penyelesaian, SS menggunakan representasi simbol untuk membuat permisalan, dalam menyelesaikan masalah menggunakan metode substitusi dengan memanfaatkan persamaan yang sudah diperoleh dari soal.

3. Pada tahap melaksanakan rencana penyelesaian, SS dalam menyelesaikan masalah menggunakan representasi simbol dengan menggunakan metode substitusi dengan memanfaatkan persamaan yang sudah diperoleh dari soal.

4. Pada tahap memeriksa kembali, SS menggunakan representasi verbal/teks tertulis. Tanpa memeriksa kembali langkah-langkah penyelesaian yang telah dilakukan SS menyakini bahwa jawabannya sudah benar, kemudian dalam menuliskan kesimpulan berupa kalimat untuk memperjelas jawaban apa yang ditanyaka

\section{Diskusi Penelitian}

Melalui penelitian ini telah diperoleh data tentang representasi siswa dalam memecahkan masalah matematika ditinjau dari kemampuan matematika siswa, namun masih terdapat beberapa kelemahan pada penelitian ini yaitu:

1. Terdapat ketidaksesuaian antara soal yang digunakan dengan instrumen yang diberikan, karena materi yang digunakan hanya SPLDV sedangkan pada soal tes pemecahan masalah (TPM) melibatkan materi SPTLDV

2. Penggunaan soal tes kemampuan matematika TKM dalam penelitian ini kurang tepat karena tidak melibatkan materi yang digunakan pada tes pemecahan masalah (TPM).

3. Terdapat ketidaksesuaian antara indikator dan hasil penelitian karena pada hasil penelitian diperoleh dua representasi yaitu representasi simbol dan verbal/katakata akan tetapi, pada indikator hanya terdapat satu representasi yaitu representasi verbal/kata-kata

\section{PENUTUP}

\section{Simpulan}

Berdasarkan hasil analisis data penelitian dan pembahasan yang dilakukan maka dapat dideskripsikan representasi siswa SMP Kemala Bhayangkari 1 Surabaya dalam memecahkan masalah matematika ditinjau dari kemampuan matematika sebagai berikut.

\section{Representasi Siswa Berkemampuan Matematika Tinggi} dalam Memecahkan Masalah Matematika

Pada tahap memahami masalah, siswa menyajikan informasi yang diketahui dengan menggunakan representasi simbol dengan membuat permisalan kemudian membuat model matematika atau persamaan. Seperti simbol $\mathrm{x}$ menyatakan jumlah porsi makanan yang dibagikan pada bulan April, simbol y menyatakan jumlah 
porsi makanan yang dibagikan pada bulan Juni, simbol $\mathrm{m}$ dengan menyatakan pengeluaran pada bulan Mei.

Kemudian menuliskan persamaan yang diketahui $\mathrm{m}=$ $2 \mathrm{x}, \mathrm{y}=6+2 \mathrm{x}, \mathrm{x}+\mathrm{y}=90$. Selain itu siswa menyajikan informasi yang ditanya dalam bentuk representasi verbal/teks tertulis, yakni berapa jumlah porsi makanan yang Dimas bagikan ke panti asuhan pada bulan April. Selanjutnya pada tahap membuat rencana penyelesaian, siswa menggunakan representasi simbol untuk membuat permisalan, seperti yang telah dilakukan pada tahap sebelumnya, dalam menyelesaikan masalah menggunakan metode substitusi dengan memanfaatkan persamaan yang sudah diperoleh dari soal. Siswa mampu menjelaskan rencana pemecahan masalah menggunakan kata-kata, dan menyusun strategis pemecahan masalah berdasarkan informasi pada soal. Sedangkan pada tahap melaksanakan rencana penyelesaian, siswa dalam menyelesaikan masalah menggunakan representasi simbol dengan menggunakan metode substitusi dengan memanfaatkan persamaan yang sudah diperoleh dari soal.

Pada tahap terakhir melihat kembali, siswa menggunakan representasi verbal/teks tertulis. Tanpa memeriksa kembali langkah-langkah penyelesaian yang telah dilakukan siswa menyakini bahwa jawabannya sudah benar, kemudian dalam menuliskan kesimpulan berupa kalimat untuk memperjelas jawaban apa yang ditanyakan.

\section{Representasi Siswa Berkemampuan Matematika Sedang dalam Memecahkan Masalah Matematika}

Pada tahap memahami masalah, siswa menyajikan informasi yang diketahui dengan menggunakan representasi verbal/teks tertulis untuk menulis kembali apa yang diketahui dari soal. Seperti pada bulan Mei dia berbagi dua kali lipat porsi makanan yang dibagikan pada bulan April, pada bulan Juni dia berbagi 6 porsi lebihnya dari jumlah makanan yang dibagikan pada bulan Mei, jumlah makanan yang dibagikan pada bulan April dan Juni adalah 90 porsi. Selain itu siswa juga menyajikan informasi yang ditanya dalam bentuk representasi verbal/teks tertulis, yakni berapa jumlah porsi makanan yang Dimas bagikan ke panti asuhan pada bulan April dan Juni serta pengeluaran pada bulann Mei. Selanjutnya pada tahap membuat rencana penyelesaian, siswa menggunakan representasi simbol untuk membuat permisalan, dalam menyelesaikan masalah menggunakan metode substitusi dengan

memanfaatkan persamaan yang sudah diperoleh dari soal. Sedangkan pada tahap melaksanakan rencana penyelesaian, siswa dalam menyelesaikan masalah menggunakan representasi simbol dengan menggunakan metode substitusi dengan memanfaatkan persamaan yang sudah diperoleh dari soal. Pada tahap akhir memeriksa kembali, siswa menggunakan representasi verbal/teks tertulis. Tanpa memeriksa kembali langkah- langkah penyelesaian yang telah dilakukan siswa menyakini bahwa jawabannya sudah benar, kemudian dalam menuliskan kesimpulan berupa kalimat untuk memperjelas jawaban apa yang ditanyakan

\section{Saran}

Berdasarkan hasil penelitian dan diskusi penelitian yang telah dijelaskan oleh peneliti pada pembahasan sebelumnya, peneliti memberikan beberapa saran sebagai berikut

1. Bagi peneliti yang akan melakukan penelitian yang sejenis, sebaiknya fokus terhadap materi yang digunakan, sehingga tidak terjadi kesalahan.

2. Bagi peneliti yang akan melakukan penelitian yang sejenis, sebaiknya memperhatikan soal TKM yang digunakan sehingga melibatkan materi yang ingin digunakan pada TPM.

3. Bagi peneliti yang akan melakukan penelitian yang sejenis, sebaiknya mempertimbangkan kemungkinan munculnya indikator representasi yang lain.

\section{DAFTAR PUSTAKA}

Alhadad, Syarifah, Fadillah. 2010. "Meningkatkan Representasi Multipel Matematis, Pemecahan Masalah Matematis dari Self Esteem siswa SMP melalui Pembelajaran dengan Pendekatan Open Ended. Disertasi: UPI. Bandung

Amri. (2019). Peningkatan Kemampuan Representasi Matematik Siswa SMP Melalui Pembelajaran dengan Pendekatan Induktif-Deduktif. Tersedia http://www.1_mtk_10009506.pdf.html

Dita, Aprilia.2016.Representasi Siswa SMP Dalam Memecahkan Maslah Masalah Ditinjau Dari Kemampuan Matematika: Skripsi Jurusan Matematika, Fakultas Matematika dan Ilmu Pengetahuan Alam, Universitas Negeri Surabaya

Goldin, G. A. (2002). Representation in mathematics learning and problem solving. In.L.D English. International Research in Mathematical

Education IRME, 197-218. New Jersey: Lawrence Erbaum Associates

Hudiono, Bambang. 2005. "Peran Pembelajaran Dikursus Multi Representasi Terhadap Pengembangan Kemampuan Matematika dan Daya Representasi pada siswa SLTP". Jurnal Cakrawala Kependidikan. Vol \& No. 2 September

Hwang, et al. 2007. " Multiple Representation Skills and Creativity Effects on Mathematical Problem Solving 
using a Multimedia Whiteboard System" Education Technology dan Society. Vol 10. No 2

Kartini, 2019. "Peranan Representasi dalam Pembelajaran Matematika". Makalah disajikan dalam Seminar Nasional Matematika dan Pendidikan Matematika Universitas Negeri Yogyakarta, Yogyakarta, 5 Desember

Leo, Adhar. 2012. Pembelajaran Matematika Dengan Metode Penemuan Terbimbing Untuk Meningkatkan Kemampuan Representasi Dan Pemecahan Masalah Matematis Siswa Smp. Pascasarjana UPI: Jurnal Pascasarjana UPI Vol. 13, No. 2, hlm 2-3

M, Duskri.2017.Kemampuan Representasi Matematika Siswa SMP Melalui Pendekatan Matematik
Realistik.Universitas Syiah Kuala, Aceh, Indonesia:Jurnal Tradis Matematika Vol. 10, No. 1, hlm 52-53

Ninik, Hariati. 2016. Representasi Matematika Siswa Dalam Memecahkan Masalah Matematika Pada Materi Lingkaran Ditinjau Dari Kemampuan Matematika Di SMP Negeri 5 Sidoarjo: Skripsi Jurusan Matematika, Fakultas Matematika dan Ilmu Pengetahuan Alam, Universitas Negeri Surabaya

NCTM. 2000. Principle And Standards For School Mathematics, VA: NCTM

Polya. George. 1973. How To Solve It. Priceton University Press. 